\author{
Kamil M. Kuśmider \\ Uniwersytet Łódzki \\ Wydziat Studiów Międzynarodowych i Politologicznych \\ ka-mix@wp.pl
}

\title{
Migracje ludności wiejskiej w Polsce - przeszłość i teraźniejszość
}

\section{Wstęp}

Rasa ludzka przemieszcza się od niepamiętnych czasów. Człowiek od początków istnienia prowadził koczowniczy tryb życia. Historia ukazuje nam spektakularne, często długotrwałe jego wędrówki kształtujące oblicze różnych obszarów.

Migracje międzynarodowe stanowią jedno z istotniejszych zjawisk społecznych nowoczesnego świata, będąc jednocześnie masowym zjawiskiem o globalnym zasięgu i wpływie, co powoduje zainteresowanie badaczy różnych dyscyplin ${ }^{1}$.

Dariusz Stola twierdzi, że „migracje są zjawiskiem godnym uwagi także dlatego, że zależą od splotu wielu czynników: demograficznych, społecznych, gospodarczych, politycznych i kulturowych. Wyjazdy zagraniczne (przynajmniej te dobrowolne) są wynikiem indywidualnych lub podejmowanych w gronie rodziny decyzji, ale jako zjawisko masowe odzwierciedlają działanie wspomnianych czynników - wyrażają przemiany społeczne, które za nimi stoją"2. Problem w Polsce nie został wywołany wstąpieniem do Unii Europejskiej, w rzeczywistości bowiem sięga on połowy XIX w., kiedy w tej części Europy wychodźstwo osiągnęło skalę masową. Wówczas to migracje przyjęły formy dobrowolnych i przymusowych, czasowych i osiedleńczych. Na ziemiach polskich objęły one ponad $20 \mathrm{mln}$ ludzi, zmieniając życie milionów rodzin, skład społeczny tysięcy wiosek, miast, wpływając tym samym na dzieje gospodarcze kraju i jego kulturę ${ }^{3}$. We Włoszech Legiony Polskie utworzono właśnie z emigrantów.

Kolejną znaczącą grupę stanowiła tzw. „wielka emigracja” po upadku powstania listopadowego, a potem intensywne migracje Polaków na przełomie XIX

1 M. Lesińska, Migracje we wspótczesnej analizie politologicznej - niewykorzystany potencjat, Ośrodek Badań nad Migracjami, CMR Working Papers 47/105, czerwiec 2011, s. 1.

2 D. Stola, Kraj bez wyjścia? Migracje z Polski 1949-1989, Instytut Pamięci Narodowej, Komisja Ścigania Zbrodni Przeciwko Narodowi Polskiemu, Instytut Studiów Politycznych PAN, Warszawa 2010, s. 7.

3 Tamże, s. 10. 
i XX w. Polskę opuszczali zarówno wrogowie państw zaborczych, jak i zwykli ludzie mający trudności w utrzymaniu się w zacofanym rolniczym kraju. Zamknięcie granic $\mathrm{w}$ okresie komunizmu również nie powstrzymało ludzi przed ucieczką, a po 1989 r. z Polski wyjechały tysiące naszych rodaków.

Autor w artykule zajmuje się: migracjami ludności z polskiej wsi, gotowością młodzieży wiejskiej do tychże wyjazdów; ich doświadczeniami migracyjnymi. Zagadnienia te wybrano $\mathrm{z}$ uwagi na fakt, iż są niezwykle aktualne i niezmiernie popularne we współczesnym świecie oraz istotne dla życia społecznego. Głównym motywem jest wykazanie, że migracja to proces, który jest wszechobecny we współczesnym społeczeństwie.

\section{Migracje jako zjawisko społeczne - motywy, czynniki i przyczyny}

Aristid R. Zolberg twierdził, że państwo w swoich działaniach politycznych ma realny wpływ na procesy migracyjne. Jako jeden z pierwszych uważał, że międzynarodowe migracje stanowią nieodłączny polityczny proces, do zadań badaczy zaś należy zmierzyć i opisać to zjawisko ${ }^{4}$. Zdaniem Jamesa Hollifielda: „polityka ma wpływ na migracje, tak jak wiele innych społecznych i ekonomicznych zjawisk, na ich marginesie. Nie znaczy to jednak, że polityka (podobnie jak kultura) jest prostą zmienną o niewielkim znaczeniu. Tak jak w każdym innym procesie społecznym, tak i w tym przypadku, to, co się często zdarza na marginesie, ma wielkie znaczenie, ale jest trudne do przeanalizowania. By użyć metafory Weberowskiej, jeśli przyrównać międzynarodowe migracje do przyspieszającego pociągu napędzanego siłami ekonomicznymi i społecznymi, to państwo jest zwrotnicą, która może zmienić bieg pociągu albo go wykoleić"5.

Motywów zachowania człowieka, zdaniem Ralpha Lintona, należy doszukiwać się w jego dążeniu do zaspakajania potrzeb: „potrzeby jednostki są właśnie tym, co tworzy motywy jej zachowania, a wskutek tego i tym, co leży u podstaw

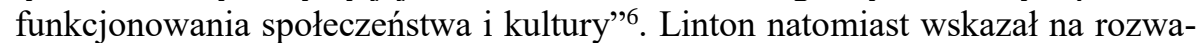
żanie trzech rodzajów potrzeb, aby zrozumieć działania podejmowane przez jednostkę: pragnienie odzewu emocjonalnego, potrzebę bezpieczeństwa i nowych doświadczeń?

Do motywów migracji zaliczamy: ekonomiczne, polityczne, społeczne i kulturowe. Wśród czynników wpływających na podjęcie decyzji przez jednostkę

$4 \quad$ A.R. Zolberg, International migration in political perspective, [w:] Global Trends in migration: theory and research on international population movements, Kritz M.M., Kelly Ch.B., Tomasi S.M., Center for Migration Studies, New York 1981, s. 68.

5 J. Hollifield, The Politics of International Migration. How Can We "Bring the State back In", [w:] Migration Theory. Talking Across Disciplines, Brettell C.B., Hollifield J., New York, London: Routledge 2000, s. 148-149.

6 R. Linton, Kulturowe podstawy osobowości, Państwowe Wydawnictwo Naukowe, Warszawa 1975, s. 65.

7 K. Podemski, Socjologia podróży, Wydawnictwo Naukowe UAM, Poznań 2004, s. 40. 
o migracji wyróżnia się ,wypychające” i „,iągnące”. Wśród motywów ekonomicznych czynniki ,wypychające” obejmują: ubóstwo, bezrobocie, niskie płace, wysoki przyrost naturalny, brak podstawowej opieki medycznej, braki w systemie edukacji, czynniki „,ciągnące” zaś to: perspektywy wyższych zarobków i poprawy standardu życia, rozwój osobisty lub zawodowy. W grupie czynników politycznych: konflikty, niebezpieczeństwo, przemoc, korupcja, łamanie praw człowieka składają się na czynniki ,wypychające”, przeciwieństwa natomiast, czyli poczucie bezpieczeństwa i wolność polityczna obejmują czynniki „ciągnące”. Do czynników ,wypychających" społecznych i kulturowych motywów zaliczamy dyskryminację wynikającą ze względów etnicznych i religijnych, natomiast łączenie rodzin, migracja do kraju przodków, brak dyskryminacji wskazują na czynniki „ciągnące"s.

Definicja migracji ludności podawana przez Główny Urząd Statystyczny (GUS) brzmi następująco: ,Migracje ludności to przemieszczenia związane ze zmianą miejsca zamieszkania (pobytu stałego lub czasowego) połączone z przekroczeniem granicy administracyjnej podstawowej jednostki terytorialnej. Migracją jest oczywiście także zmiana kraju zamieszkania"9. Migracją jest również zmiana gminy zamieszkania, przeniesienie się z miasta na wieś lub odwrotnie $\mathrm{w}$ tej samej gminie albo zmiana kraju zamieszkania ${ }^{10}$. Ze względu na obszar migracje dzielą się na wewnętrzne (zmiany miejsca zamieszkania na terenie kraju ${ }^{11}$ ) oraz zewnętrzne (przemieszczenia odbywające się poza granice kraju). „Migracje zagraniczne to wyjazdy za granicę i przyjazdy do kraju w celu osiedlenia się (zamieszkania na stałe) lub na pobyt czasowy"12.

\section{Migracje ludności wiejskiej}

\section{Rys historyczny}

Ludność wiejska w Polsce przemieszczała się głównie do innych wsi oraz do miast, mając na uwadze poszukiwanie pracy w czasie rozkwitu zakładów produkcyjnych. Największy napływ ludności wiejskiej do miast odnotowano w 1956 r. (750 tys.), potem nastąpił spadek do 666 tys. w 1960 r. Istotny był tutaj

8 Bank Światowy, Migration and Remittances. Easter Europe and the former Soviet Union, New York 2006, s. 52.

9 https://stat.gov.pl/metainformacje/slownik-pojec/pojecia-stosowane-w-statystycepublicznej/845,pojecie.html?contrast=default, (dostęp: 19.12.2019)

10 Z. Kostrzewa, J. Stańczak, Migracje dlugookresowe ludności w latach 1989-2002, GUS, Warszawa 2004, s. 21.

11 https://stat.gov.pl/metainformacje/slownik-pojec/pojecia-stosowane-w-statystycepublicznej/212,pojecie.html, (dostęp: 19.12.2019).

12 https://stat.gov.pl/metainformacje/slownik-pojec/pojecia-stosowane-w-statystycepublicznej/213,pojecie.html, (dostęp: 19.12.2019). 
również wzrost zaludnienia miast. Jednakże była to wielkość znacznie wyższa, o 165 tys. od danych z początkowego $1951 \mathrm{r}$. W migracjach ludności wiejskiej dominujący był przepływ między wsiami a wsiami. Należy zaznaczyć, iż ruchliwość przestrzenna dotyczyła jednocześnie napływu do wsi, jak i odpływu ze wsi. W tym ostatnim odnotowano dwa maksima: w 1954 r. (815 tys.) i w 1959 r. $(830 \text { tys. })^{13}$. Należy podkreślić, że współczynniki ruchu wędrówkowego ludności wsi początkowo były znacznie niższe od odpowiednich współczynników dla miast. Jednakże w kolejnych pięcioleciach widoczny był wzrost przepływów ludności ze wsi na wieś. Wówczas odnotowano średnią rocznie na poziomie z 380 do 480 tys. W efekcie w pierwszym pięcioleciu przepływy ze wsi na wieś kształtowały się na poziomie wzrostu z nieco ponad jednej czwartej do ponad jednej trzeciej w drugim pięcioleciu ${ }^{14}$.

W Polsce do około 1996 r. najbardziej widoczna była migracja ze wsi do miast. Ludzie byli ciekawi nowego i lepszego, ich zdaniem, życia wielkomiejskiego, tym samym uciekali z biednych polskich wsi. Towarzyszyło temu częste poczucie wstydu związanego $z$ wiejskim pochodzeniem. Po II wojnie światowej, ludowe z nazwy państwo kreowało jednak wizrunek tradycyjnej wsi jako zacofanej gospodarczo i mentalnie, tkwiącej w katolicyzmie. Miasto miało dać i dawało nowe możliwości, wykształcenie, pracę, ale przede wszystkim dostęp do kultury, ośrodków naukowych, oświatowych czy handlowych oraz służby zdrowia. W latach 50. i 70. XX w. odnotowano największy przepływ ludności ze wsi do miast, głównie w intensywnie rozwijających się: Dolnym i Górnym Śląsku oraz Zachodniopomorskiem. Przy nowych zakładach powstawały osiedla mieszkaniowe, co także kusiło ludność do wędrówek. Od lat 90. minionego wieku nastąpił spadek tychże migracji. Obecnie ludność wiejska o niezbyt wysokim wykształceniu, nie widzi w migracji do miast skutecznego sposobu na znalezienie pracy. Jest to spowodowane ogólną informacją, iż nawet osoby $\mathrm{z}$ wykształceniem mają problemy $\mathrm{z}$ zatrudnieniem w mieście. Wpływa na to również zmiana struktury gospodarki, a w konsekwencji mniejsze zapotrzebowanie na pracowników. Do miast udają się głównie ludzie młodzi w celu zdobywania wykształcenia, bardzo wielu tutaj pozostaje i znajduje pracę. Niektórzy po zakończeniu nauki w zakresie prowadzenia i rozwoju gospodarstwa rolnego wracają do swojego miejsca pochodzenia, by prowadzić np. hodowlę, plantacje. Migracja ze wsi do wsi odnosi się do przepływów wewnętrznych w obrębie danego regionu.

Analizując migracje zagraniczne Polaków w latach 1990-2010 zauważyć można, że większość migrantów udających się na obczyznę na stałe pochodziło z miast. W roku 2005 nastąpiło ogromne ożywienie wśród wyjeżdżających ze wsi za granicę - aż 14 tys. osób z miast i ok. 5 tys. ze wsi ${ }^{15}$. Według danych GUS-u

13 L. Kosiński, Migracje ludności w Polsce w latach 1950-1960, Instytut Geografii Polskiej Akademii Nauk, „Prace Geograficzne” nr 72, Państwowe Wydawnictwo Naukowe, Warszawa 1968 , s. 30.

14 Tamże, s. 31-32.

15 Z. Długosz, Wybrane aspekty statej emigracji ludności z Polski za granicę po 1989 roku, „Czasopismo Geograficzne” nr 78 (1-2), Wrocław 2007 s. 3-22. 
w latach 1989-2002, mając na uwadze migracje międzywojewódzkie, przemieszczeń ze wsi do miast było ok. 22\% i ze wsi na wieś ok. $11 \%$. Najwięcej odpływów odnotowano w województwach: dolnośląskim, mazowieckim i śląskim, natomiast największe napływy miały miejsce w śląskim i małopolskim ${ }^{16}$. Lata $2002-$ 2007 charakteryzowały się wzrostem zarówno liczby migracji ze wsi do miast, jak i z miast do wsi. Większy wzrost osiągał jednak ten drugi kierunek. W roku 2007 migracja ze wsi do miast osiągnęła pułap 116,5 tys. osób. Zaznaczyć należy, $\mathrm{iż} \mathrm{w}$ tym czasie wyższy poziom osiągnęła migracja $\mathrm{z}$ miast na wieś, bo aż 164,5 tys. osób ${ }^{17}$.

Współczesna polska wieś zmieniła się na lepsze, jest bogatsza i atrakcyjniejsza. Tereny są ekologiczne, a zdrowe środowisko i spokój zachęcają do zamieszkania. Należy podkreślić, że w Polsce aż 38\% ludności mieszka na wsi, podobnie jak w Finlandii, Szwajcarii czy Grecji. Według danych GUS-u w 2011 r. około 15 mln 332 tys. osób mieszkało na wsiach, a około 23 mln 169 tys. (ok. 60\% ogółu) zamieszkiwało tereny miejskie ${ }^{18}$.

\section{Migracje wewnętrzne}

W Polsce przepływy wewnętrzne często odbywają się pomiędzy sąsiadującymi ze sobą województwami, co wynika przede wszystkim z sytuacji regionalnego rynku pracy i nieco mniej z warunków bytowania ${ }^{19}$. Według Jerzego Bańskiego migracje wewnętrzne - ze wsi do miast - to proces trwały ${ }^{20}$. Jego zdaniem „nie należy go oceniać negatywnie, ale trzeba ograniczyć selektywność migracji, bo odpływają lepiej wykształceni i aktywni" ${ }^{21}$.

Decyzje o migracjach wewnętrznych podejmowane są głównie przez młodych ludzi do 24 roku życia, są one bowiem ściśle związane $\mathrm{z}$ nauką. $Z$ migracjami wewnętrznymi nierozerwalne są migracje wahadłowe, które polegają na przemieszczaniu się w celu codziennego dojazdu do pracy do innej miejscowości.

16 Tamże, s. 30-36.

17 D. Nowotnik, Przestrzenne zróżnicowanie migracji $w$ Polsce $w$ ujęciu miast $i$ gmin na przełomie XX i XXI wieku, Uniwersytet Pedagogiczny im. Komisji Edukacji Narodowej w Krakowie, Annales Universitatis Paedagogicae Cracoviensis, Studia Geographica III (2012), FOLIA 126, s. 142.

18 Wyniki Narodowego Spisu Powszechnego Ludności i Mieszkań 2011. Podstawowe informacje o sytuacji demograficzno-społecznej ludności Polski oraz zasobach mieszkaniowych, GUS, Warszawa 2012, s. 7, pdf na: https://stat.gov.pl/spisy-powszechne/nsp-2011/nsp2011-wyniki-wstepne/wyniki-narodowego-spisu-powszechnego-ludnosci-i-mieszkan2011,3,1.html, (dostęp: 31.12.2019).

19 J. Wilk, M.B. Pietrzak, Analiza migracji wewnętrznych w kontekście aspektów spoleczno-gospodarczych - podejście dwuetapowe, „Ekonometria” 2 (40), Wrocław 2013, s. 69.

20 J. Bański, Przemiany polskiej wsi, Instytut Geografii i Przestrzennego Zagospodarowania PAN, Warszawa 2010, s. 18.

21 Tamże, s. 20. 
Migrant wahadłowy poświęca na dojazd przeciętnie 56 minut ${ }^{22}$. Młodzi ludzie, w przeciwieństwie do starszych, nie posiadają jeszcze tak trwałych przyzwyczajeń i tak silnych więzi rodzinnych, przez co nie są ograniczani w mobilności.

Badacze stawiają sobie zasadnicze pytanie „Czy migracje wewnętrzne są cichym zabójcą wsi?”. Obszary wiejskie w naszym kraju, co wynika z analiz Monitoringu Rozwoju Obszarów Wiejskich (MROW), mocno się zmieniają. Zaznacza się zmiana obrazu polskiej wsi. Widać mniej rejonów i mieszkańców wsi zajmujących się rolnictwem. Jak zauważają autorzy badań mają na to wpływ głównie migracje wewnętrzne. Wyniki III etapu MROW pokazują, że na 100 mężczyzn mieszkających na wsi przypada tylko 91 kobiet. Co istotne, nie zmienia się to od 2014 r. (I etap badania) ${ }^{23}$.

Jak podkreśla dr hab. Monika Stanny, dyrektor Instytutu Rozwoju Wsi i Rolnictwa PAN i jednocześnie kierownik projektu realizującego MROW, w migracjach wewnętrznych uczestniczą przede wszystkim ludzie młodzi, dobrze wykształceni, zaradni i przedsiębiorczy. Migracje mają istotny wpływ na zmiany zaludnienia i struktury demograficzne oraz na rynek pracy i potrzeby w usługach publicznych. Wyniki III etapu MROW wskazują, iż najchętniej i najwięcej migrują ze wsi kobiety w wieku 25-34 lat. Jedynie w gminach podmiejskich, głównie w sąsiedztwie Warszawy, Poznania czy Trójmiasta widoczna jest przewaga zamieszkujących kobiet nad mężczyznami, którzy wyjechali za pracą. Niestety na obszarach biednych, tzw. popegeerowskich, zamieszkuje znacznie mniej kobiet ${ }^{24}$.

Według Łukasza Zwolińskiego głównym powodem migracji osób z gospodarstw rolnych była ich likwidacja, co powodowało, iż ze statusu rolnego przeszli na bezrolny (wśród badanych: mężczyźni 50,1\%, kobiety 49,9\%). Grupę stanowili mieszkańcy w wieku 45-59 lat $(41,8 \%)$ z wykształceniem podstawowym $(51,9 \%)$. Pozostałymi motywami migrowania $z$ gospodarstw rolnych były sprawy rodzinne, zarobkowe i mieszkaniowe ${ }^{25}$.

Zdaniem Moniki Stanny: „Wśród osób migrujących kobiety z reguły przeważały i przeważają nad mężczyznami. Zjawisko to często określane jako »brak potencjalnych żon dla rolników «i dotyczy grup mieszkańców w wieku od 25 do 34 lat. Jest ono powodowane nie tylko poszukiwaniem pracy, ale także tym, że lokalne społeczności, szczególnie te składające się z osób starszych i słabo wykształconych, często mniej chętnych wobec wprowadzanych innowacji, przestają

22 B. Leszczyńska, S. Nowak, K. Reński, B. Rokicki, P. Stronkowski, I. Szczepocka, Wpływ funduszu Unii Europejskiej na saldo migracji wewnętrznych i zewnętrznych $w$ Polsce, WYG PSDB, Warszawa 2009, s. 50-52.

23 M. Stanny, A. Rosner, Ł. Komorowski, Monitoring rozwoju obszarów wiejskich. Etap III Struktury społeczno-gospodarcze, ich przestrzenne zróżnicowanie $i$ dynamika, Fundacja Europejski Fundusz Rozwoju Wsi Polskiej Instytut Rozwoju Wsi i Rolnictwa PAN, Warszawa 2018, s. 115-120. Tamże, s. 128.

25 Ł. Zwoliński, Mobilność przestrzenna i społeczno-zawodowa ludności wiejskiej w latach 2000-2005, nr 29, Instytut Ekonomiki Rolnictwa i Gospodarki Żywnościowej Państwowy Instytut Badawczy, Warszawa 2006, s. 34-35. 
być dla młodych osób atrakcyjnym miejscem do realizacji aspiracji życiowych" 26 . Niestety w takiej sytuacji na obszarach wiejskich znacznie trudniej jest zapobiegać problemom starzejącego się społeczeństwa.

\section{Migracje zewnętrzne}

Migracje zagraniczne ludności wiejskiej od wielu lat nie ulegały intensywnym zmianom, utrzymując się dość długo na tym samym poziomie. Jednakże w porównaniu do lat 1996-2000 nastąpił ich wzrost wśród ludności wiejskiej. Na wyjazdy zagraniczne w latach 2000-2005 zdecydowało się 11,6\% mieszkańców wsi. Najczęściej były to osoby mieszkające w makroregionie południowo-wschodnim i południowo-zachodnim naszego kraju. Wśród krajów docelowych wybieranych przez emigrantów były: Niemcy, Wielka Brytania, Holandia, Irlandia i Włochy. W tym czasie najmniej ludności wiejskiej, w odniesieniu do całej migracji przestrzennej, zdecydowało się na migrację zagraniczną $\mathrm{w}$ makroregionach środkowo-zachodnim oraz północnym. Ci podejmowali się wyjazdów do miast czy do innych wsi w kraju. Mając na uwadze płeć migrantów podkreślić należy, iż częściej byli to mężczyźni, w większości legitymujący się nie tylko wykształceniem zasadniczym zawodowym. Były to osoby młode z lepszym poziomem wykształcenia.

Jak wskazuje Łukasz Zwoliński: „W badaniu z 2005 roku żadna z osób emigrujących wśród ludności bezrolnej nie posiadała wykształcenia wyższego, co przyczyniło się do zaniżenia ogólnego udziału osób z tym właśnie wykształceniem. Dla porównania w latach 1996-2002 wyjechało 16,7\% osób z rodzin bezrolnych oraz $11,1 \%$ z rodzin rolniczych z wykształceniem wyższym. Osoby emigrujące jako główny powód migracji wskazywały motywy zarobkowe $(84,2 \%$ osób z rodzin bezrolnych i 55,1\% osób z rodzin rolniczych). Innym motywem migracji były sprawy rodzinne, które stanowiły przyczynę migracji $15,8 \%$ osób $\mathrm{z}$ rodzin bezrolnych oraz $26,5 \%$ osób z rodzin rolniczych. Motywami rodzinnymi głównie kierowały się kobiety $(66,7 \% \mathrm{z}$ rodzin bezrolnych oraz $76,9 \% \mathrm{z}$ rodzin rolniczych), a zarobkowymi mężczyźni $(62,5 \%$ z rodzin bezrolnych oraz $63 \%$ z rodzin rolniczych)"27. Mając na uwadze Polaków rozważających emigrację zarobkową należy podkreślić, iż $50 \%$ stanowią osoby pochodzące ze wsi. Według danych Work Service z maja 2018 r. deklaracje takie złożyli również Polacy z miast do 100 tysięcy mieszkańców (razem stanowią $69 \%)^{28}$.

Jak widać potencjalni migranci nadal upatrują $\mathrm{w}$ wyjazdach zagranicznych lepszego życia i zarobkowania.

26 M. Stanny, A. Rosner, Ł. Komorowski, dz. cyt., s. 21.

27 Ł. Zwoliński, dz. cyt., s. 43-47.

28 Migracje zarobkowe Polaków VIII-maj 2018 r., http://www.workservice.com/pl/Centrumprasowe/Raporty/Raport-Migracyjny/Migracje-Zarobkowe-Polakow-VIII-maj-2018, (dostęp: 19.12.2019). 


\section{Struktura płci i wieku migrantów zagranicznych na stałe}

Poziom i dynamika rozwoju społeczno-demograficznego wiąże się ściśle $\mathrm{z}$ procesami migracyjnymi. Jest to widoczne $\mathrm{w}$ momencie przemieszczania się ludności z obszarów niżej rozwiniętych do tych znajdujących się na wyższym poziomie rozwoju, co odnosi się do selektywności migracji.

Według Ravensteina migracje są selektywne, podejmowane są bowiem w większości przez ludzi młodych ${ }^{29}$. Kierunkami obieranymi przez nich są miejsca pozarolnicze oferujące pracę. Selekcja ta obejmuje następujące cechy: wiek, płeć, wykształcenie i przedsiębiorczość osób migrujących. Tym samym stwierdzić należy, że migracje mają wpływ jednocześnie na zaludnienie oraz strukturę ludności zarówno w środowisku odpływu, jak i napływu migrantów. Mając na uwadze selektywność migracji ze względu na wiek, w strumieniu odpływu ze wsi widoczna jest zwykle silna reprezentacja osób młodych, którzy kończąc okres edukacji, wchodzą $\mathrm{w}$ wiek podejmowania samodzielnych decyzji, pracy zarobkowej, a także zakładają własne rodziny i gospodarstwa domowe ${ }^{30}$. Na szczytowe natężenie migracji $\mathrm{w}$ danym okresie wpływają istotnie następujące czynniki, m.in.: czas trwania edukacji, sytuacja na rynku pracy, znalezienie zakwaterowania odpowiadającego możliwościom utrzymania w miejscu docelowym ${ }^{31}$.

Jak zauważają Izabela Grabowska-Kucińska i Marek Okólski, zarówno przed akcesją Polski do Unii Europejskiej, jak i później, migranci zagraniczni pochodzący ze wsi byli młodsi od migrantów zagranicznych z miast ${ }^{32}$. Potwierdzają to również wyniki raportu „Młodzi 2011”, dokonując bowiem ich analizy, zauważyć można silne oddziaływanie zjawiska migracji młodych na potencjał regionów. Należy odnotować, iż może być ono pozytywne lub negatywne, zależnie od napływów i odpływów ${ }^{33}$.

29 A. Runge, Procesy i struktury ludnościowe $w$ województwie ślaskim, [w:] Procesy i struktury demograficzno-społeczne na obszarze województwa śląskiego w latach 19882008, Urząd Statystyczny w Katowicach, Katowice 2010, s. 60.

30 A. Rosner, Migracje wewnętrzne i ich zwiazek z przestrzennym zróżnicowaniem rozwoju społeczno-gospodarczego wsi, „Wieś i Rolnictwo” nr 1 (162), PAN, Warszawa 2014, s. 63-79.

31 I. Frenkel, A. Rosner, Infrastruktura wiejska a migracje między miastem i wsia, [w:] Studia nad migracjami ludności wiejskiej. Monografie i opracowania, SGPiS, Warszawa 1986, s. 199.

32 I. Grabowska-Lusińska, M. Okólski, Emigracja ostatnia? Cechy osób migrujących przed akcesja i po niej, Wydawnictwo Naukowe Scholar, Warszawa 2009, s. 230.

33 K. Szafraniec, Raport „Młodzi 2011”, Kancelaria Prezesa Rady Ministrów, Warszawa 2011, s. 69. 


\section{Migracje młodych z polskiej wsi - doświadczenia i gotowość do wyjazdów}

Obecnie młodzi ludzie są świadomi zasad funkcjonowania współczesnego świata. Główną energię kierują na inwestycje w siebie, wiedzą bowiem, że może to zaprocentować $\mathrm{w}$ przyszłości.

Zaznaczyć trzeba, że młodzi Polacy spodziewają się braku lub znikomego napięcia w przyszłej pracy, mniej stresów oraz stabilności i rozwoju zawodowego. Zauważają to za granicą, patrząc na sukcesy osiągane przez emigrantów. Ważne dla nich są korzystniejsze warunki egzystencji i pracy oraz wyższy standard życia (33\%), możliwość podróżowania i zwiedzania świata (23\%), lepsza służba zdrowia (22\%) czy lepsze warunki socjalne (18\%). Czynnikiem motywującym do wyjazdu jest również środowisko zawodowe, a dokładnie perspektywy rozwoju kariery (np. 265 badanych podało to jako powód wyjazdu do Wielkiej Brytanii). Kolejnymi czynnikami motywującymi były: brak odpowiedniej pracy w Polsce $(23 \%)$ oraz wyższy poziom kultury zawodowej w Wielkiej Brytanii $(14 \%)^{34}$. Opłacalność wyjazdu, możliwość uzyskania wyższego wynagrodzenia, nawet kilkakrotnie za tę samą pracę, oraz poczucie bezpieczeństwa stanowią o polskim exodusie do Wielkiej Brytanii ${ }^{35}$. Profesor Krystyna Iglicka zauważyła, że: „Młodzi ludzie szukają lepszego życia. [Emigranci - przyp. K.K.] wiedzą, że normalne życie jest na wyciągnięcie ręki i korzystają z tego"36. Młode pokolenie Polaków jest gotowe stawić czoła nowym wyzwaniom, problemom, będąc jednocześnie samodzielnymi i odpowiedzialnymi. Młodzi wiedzą, że taki wyjazd może nie być wyłącznie zarobkowy, ale będzie formą spędzania czasu, doskonaleniem języka obcego i gromadzeniem doświadczenia, a dla niektórych zawarte znajomości mogą przyczynić się do rozpoczęcia kariery w Wielkiej Brytanii.

Jak potwierdza psycholog społeczny Janusz Czapiński, wyjazd młodzieży nie jest już ucieczką przed bezrobociem, ale poszukiwaniem szans na rozwój zawodowy $^{37}$.

Wyniki badań autora artykułu przeprowadzonych wśród studentów łódzkich uczelni (Uniwersytetu Łódzkiego, Politechniki Łódzkiej i Społecznej Akademii Nauk) w roku akademickim 2015/2016 i 2016/2017 potwierdzają teorie i pokazują, że doświadczenia migracyjne z różnych miejsc pochodzenia prezentowały się różnie. W badaniach wzięło udział 129 respondentów pochodzących ze wsi, w tym 87 kobiet (31\%) i 42 mężczyzn (15\%) z dwóch poziomów studiów: I stopnia - 43 kobiety (31\%) i 22 mężczyzn (17\%); II stopnia - 44 kobiety (34\%) i 20 mężczyzn (16\%). Na poziomie III stopnia nie było respondentów pochodzących ze wsi. Respondenci pochodzący ze wsi preferują w przyszłości inną miejscowość

34 Polacy chca nadal emigrować do Wielkiej Brytanii, http://londynek.net/wiadomosci/article?jdnews_id=25782 (dostęp: 19.12.2019).

35 R. Jończy, Exodus zarobkowy opolskiej młodzieży, „Polityka Społeczna” nr 10, XXXIII, Warszawa 2006, s. 12.

36 Kierunki emigracji zarobkowej, http://rynekpracy.pl/artykul.php/wpis.766, (dostęp: 19.12.2019).

37 J. Ćwiek, Polacy znów masowo emigrują do Londynu, „Rzeczpospolita”, 25.09.2012. 
zamieszkania (35\%), ale w tym samym województwie, następnie obecną miejscowość $(25 \%)$, inne województwo (14\%). Zagranicę wskazało $25 \%$ badanych. Wśród studentów poszukujących pracy: $46 \%$ znalazło pracę w mieście, nie znalazło jej 24\%, 35\% zaś nie szukało zatrudnienia. Studenci ze wsi szanse znalezienia pracy na zagranicznym rynku oceniają na poziomie bardzo dobrym $(10 \%)$, dobrym (15\%), słabym (21\%). Natomiast prawie $40 \%$ badanych ze wsi, twierdzi, że nie ma zdania na ten temat. Zainteresowanie pracą w Wielkiej Brytanii wśród studentów ze wsi jest spore: „Zdecydowanie tak” odpowiedziało 15\%, a „raczej” $-25 \%$. Respondenci na pytanie „Czy ma Pani/Pan kogoś w gronie rodziny, znajomych, którzy przebywali lub przebywają w Wielkiej Brytanii?" odpowiedzieli: $58 \%$ nikogo, $17 \%$ rodzinę, a $25 \%$ znajomych. Przypuszczalny czas pobytu w Wielkiej Brytanii dotyczy planów podjęcia pracy w okresie sezonowym czy też podczas wakacji (35\%). Pracą trwającą nie dłużej niż rok zainteresowanych jest $22 \%$, aż $32 \%$ badanych pochodzących ze wsi chciałoby pracować dłużej niż rok, ci sami respondenci myślą o wyjeździe na stałe (11\%). Analizując warunki stanowiące o gotowości ankietowanych do pracy w Wielkiej Brytanii, widać, że głównym motywem jest wyższe wynagrodzenie (45\%). Na pozostałe wskazali: wyuczony zawód (33\%), praca bez wykorzystania kwalifikacji (22\%). Wśród aspektów cenionych przez badanych podczas pobytu w Wielkiej Brytanii wyróżnili: plany zawodowe $(22 \%)$, usamodzielnienie się, zdobycie doświadczenia związanego z mieszkaniem za granicą (18\%) i doświadczenia zawodowe (18\%). Niektórzy z badanych wymienili: „wyższe zarobki”, ,jakość życia”, „duże pieniądze". Stopień przydatności zdobytego doświadczenia w przyszłej karierze $39 \%$ ankietowanych ocenia znacząco, 22\% umiarkowanie, 13\% minimalnie, a $21 \%$ niedostatecznie i $2 \%$ istotnie. Głównymi motywami wyjazdu z Polski dla respondentów są: wyjazd zarobkowy (36\%), nowe doświadczenie w życiu (19\%), doskonalenie języka obcego (16\%) oraz poznanie nowych kultur $(8 \%)$ i ciekawość (7\%). Badani studenci ocenili swoje możliwości zaadaptowania się w Wielkiej Brytanii na poziomie: umiarkowanym (44\%), znacząco (33\%) i minimalnie (12\%), co wynika zapewne z mniejszych możliwości kontaktów w tym kraju. Ankietowani mając na uwadze efekty wyjazdu, wskazali przede wszystkim na osiągnięcie zysków (75\%), na straty zaś tylko $10 \%$. W skutecznej adaptacji do społeczeństwa w Wielkiej Brytanii przede wszystkim pomoże studentom znajomość języka (36\%), wsparcie bliskich (33\%), jak również cechy osobowości - komunikatywność czy zaradność (25\%). Korzyści z wyjazdu dla badanych to głównie finanse (36\%) i rozwój umiejętności językowych (17\%). Wśród powodów wpływających na rezygnację z zamiaru pracy za granicą badani wskazali jako główny podjęcie pracy na stałe w Polsce $(45 \%)$ i namowy rodziny $(25 \%)$. Studenci ocenili swój status materialny jako dostateczny (40\%) i dobry (31\%), a w najmniejszym stopniu jako bardzo dobry (12\%). Wyniki badań pokazują, że respondenci swoje możliwości w zaspokojeniu potrzeb materialnych postrzegają również na poziomie niedostatecznym (17\%). Doświadczenie pracy w Wielkiej Brytanii posiada niewielu studentów, bo zaledwie $9 \%$. Wynika to być może z braku konieczności zarabiania za granicą albo też z braku perspektywy załatwienia takiej pracy. Moż- 
liwość zarobkowania w Wielkiej Brytanii po zakończeniu studiów, pomimo doświadczeń, widzi 45\% studentów. Niektórzy mieli okazję pracować w Wielkiej Brytanii i swój pobyt oceniają korzystnie pod względem finansowym (40\%); respondenci docenili wysoko płatną pracę $(27 \%)$ oraz zdobyte doświadczenie $(21 \%)$.

\section{Zakończenie}

Zjawisko migracji dla współczesnej cywilizacji nie jest czymś nowym, a jej główny kierunek w europejskim obszarze przebiega ze Wschodu na Zachód. Zagadnienie migracji zagranicznych jest bardzo obszerne, a podjęta przez autora analiza, dopełniona studiami literaturowymi, stanowi zaledwie wycinek problematyki tego zjawiska. Zasadniczym celem pracy autora było przybliżenie przebiegu procesów emigracyjnych w wymiarze polityczno-społecznym oraz ukazanie struktury odpływu Polaków do Wielkiej Brytanii, a także rozpoznanie przyczyn i motywów skłaniających młodych ludzi pochodzących ze wsi do wyjazdu z kraju i ich planów na przyszłość. Wszystkie obserwowane tendencje były uwarunkowane przede wszystkim czynnikami o charakterze ekonomicznym i należy uznać, że opisywane w artykule zjawiska są efektem dostosowywania się wiejskiej społeczności do nowych warunków gospodarczych oraz poszukiwania możliwości awansu społeczno-ekonomicznego.

W oparciu o powyższe rozważania zawarte w artykule oraz dokonaną analizę można stwierdzić, że przystąpienie Polski do Unii Europejskiej, a tym samym wynikająca $\mathrm{z}$ tego możliwość korzystania z zasad jednolitego rynku europejskiego i swoboda przepływu osób, wpłynęły znacząco na wielkość i dynamikę emigracji z Polski. Najbardziej mobilnymi regionami kraju okazały się makroregiony północny i południowo-zachodni, najczęściej zaś wybieranym kierunkiem migracji ludności ze wsi - miasto. Nastąpiło zmniejszenie migracji wewnętrznych (zwłaszcza wśród ludności rolniczej) i zwiększenie migracji zagranicznych. Głównym motywem przemieszczenia się respondentów były czynniki ekonomiczne. Ludzie odczuwają potrzebę polepszenia warunków życia. Wśród studentów wyraźnie przeważają dwa typy wyjazdów: wyjazdy zarobkowe na okres sezonowy i wyjazdy planowane na dłużej. Pracą trwającą nie dłużej niż rok zainteresowanych jest $22 \%$ osób pochodzących ze wsi. Zamiar zamieszkania za granicą deklarowało $25 \%$. Spośród powodów zarobkowych wyjazdów za granicę dominują powody ekonomiczne, a następnie edukacyjne - doskonalenie znajomości języka obcego, zdobycie doświadczenia zawodowego oraz usamodzielnienie się. Doświadczenia migracyjne studentów pochodzących ze wsi wskazują na niski poziom w tym zakresie (9\%). Jednakże niektórzy z nich pozytywnie ocenili swój pobyt na emigracji, głównie sukces finansowy. Profil typowego emigranta ze wsi, który ma zamiar wyjechać za granicę, rysuje się następująco: nieco częściej mężczyzna niż kobieta; nieco częściej osoba pierwszego stopnia studiów; osoba deklarująca dobrą znajomość języka angielskiego; osoba o wysokich oczekiwaniach dotyczących wysokości wynagrodzenia. 
Polscy migranci, bez względu na miejsce pochodzenia, są zdeterminowani, mobilni i przedsiębiorczy, mają swój plan na życie. Poprawa warunków i wzrost konkurencji na polskim rynku pracy może nie tylko powstrzymać wyjazdy, zwłaszcza młodego pokolenia, ale też $\mathrm{w}$ znaczny sposób zachęcić do powrotów $\mathrm{z}$ emigracji.

\section{Summary}

\section{Migrations of Rural Population in Poland - the Present and the Past}

Migration is an integral part of human history. International migrations are one of the most important social phenomena in the modern world and in Poland. Their trends and reasons, shaping up in time, are the fundation for conducting research into this process. The scale of the departures also makes the problem increasingly significant for social researchers. The article presents the essence of contemporary migrations of Poles from the countryside and most of all, it shows readiness of young people to move abroad. It shows the scope of migration and the main features of contemporary Polish migration. It was developed based on the result of research, which was conducted among high school students who had been demonstrating readiness to migrate.

Keywords: international migrations, migrations Poles, school students

\section{Bibliografia}

Opracowania

Bank Światowy, Migration and Remittances. Easter Europe and the former Soviet Union, New York 2006.

Bański J., Przemiany polskiej wsi, Instytut Geografii i Przestrzennego Zagospodarowania PAN, Warszawa 2010.

Ćwiek J., Polacy znów masowo emigruja do Londynu, „Rzeczpospolita”, 25.09.2012.

Długosz Z, Wybrane aspekty stałej emigracji ludności z Polski za granice po 1989 roku, „Czasopismo Geograficzne" nr 78 (1-2), Wrocław 2007.

Frenkel I., Rosner A., Infrastruktura wiejska a migracje między miastem i wsia, [w:] Studia nad migracjami ludności wiejskiej. Monografie i opracowania, SGPiS, Warszawa 1986.

Grabowska-Lusińska I., Okólski M., Emigracja ostatnia? Cechy osób migrujących przed akcesją i po niej, Wydawnictwo Naukowe Scholar, Warszawa 2009.

Hollifield J., The Politics of International Migration. How Can We "Bring the State back In" [w:] Migration Theory. Talking Across Disciplines, Brettell C.B., Hollifield J., New York, London: Routledge 2000.

Jończy R., Exodus zarobkowy opolskiej młodzieży, „Polityka Społeczna” nr 10, XXXIII, Warszawa 2006.

Kosiński L., Migracje ludności w Polsce w latach 1950-1960, [w:] Migracje dlugookresowe ludności w latach 1989-2002, Kostrzewa Z., Stańczak J., GUS, Warszawa 2004.

Lesińska M., Migracje we wspótczesnej analizie politologicznej - niewykorzystany potencjat, Ośrodek Badań nad Migracjami, CMR Working Papers 47/105, czerwiec 2011. 
Leszczyńska B., Nowak S., Reński K., Rokicki B., Stronkowski P., Szczepocka I., Wpływ funduszu Unii Europejskiej na saldo migracji wewnętrznych i zewnętrznych w Polsce, WYG PSDB, Warszawa 2009.

Linton R., Kulturowe podstawy osobowości, Państwowe Wydawnictwo Naukowe, Warszawa 1975.

Nowotnik D., Przestrzenne zróżnicowanie migracji w Polsce $w$ ujęciu miast $i$ gmin na przełomie XX i XXI wieku, Uniwersytet Pedagogiczny im. Komisji Edukacji Narodowej w Krakowie, Annales Universitatis Paedagogicae Cracoviensis, Studia Geographica III (2012), FOLIA 126.

Podemski K., Socjologia podróży, Wydawnictwo Naukowe UAM, Poznań 2004.

Rosner A., Migracje wewnętrzne i ich zwiąek z przestrzennym zróżnicowaniem rozwoju spoteczno-gospodarczego wsi, „Wieś i Rolnictwo”, nr 1 (162), PAN, Warszawa 2014.

Runge A., Procesy i struktury ludnościowe w województwie śląskim, [w:] Procesy i struktury demograficzno-spoteczne na obszarze województwa śląskiego w latach 1988-2008, Urząd Statystyczny w Katowicach, Katowice 2010.

Stanny M., Rosner A., Komorowski Ł., Monitoring rozwoju obszarów wiejskich. Etap III Struktury społeczno-gospodarcze, ich przestrzenne zróżnicowanie i dynamika, Fundacja Europejski Fundusz Rozwoju Wsi Polskiej Instytut Rozwoju Wsi i Rolnictwa, PAN, Warszawa 2018.

Stola D., Kraj bez wyjścia? Migracje z Polski 1949-1989, Instytut Pamięci Narodowej, Komisja Ścigania Zbrodni Przeciwko Narodowi Polskiemu, Instytut Studiów Politycznych PAN, Warszawa 2010.

Szafraniec K., Raport „,Młodzi 2011 ”, Kancelaria Prezesa Rady Ministrów, Warszawa 2011.

Wilk J., Pietrzak M.B., Analiza migracji wewnętrznych w kontekście aspektów społeczno-gospodarczych-podejście dwuetapowe, „Ekonometria” 2 (40), Wrocław 2013.

Zolberg A. R., International migration in political perspective, [w:] Global Trends in migration: theory and research on international population movements, Kritz M.M., Kelly Ch.B., Tomasi S.M., Center for Migration Studies, New York 1981.

Źródła internetowe

Definicje GUS, https://stat.gov.pl/metainformacje/slownik-pojec, (dostęp: 19.12.2019).

Kierunki emigracji zarobkowej, http://rynekpracy.pl/artykul.php/wpis.766, (dostęp: 19.12.2019).

Migracje zarobkowe Polaków VIII - maj 2018 r., http://www.workservice.com/pl/Centrumprasowe/Raporty/Raport-Migracyjny/Migracje-Zarobkowe-Polakow-VIII-maj-2018, (dostęp: 19.12.2019).

Polacy chca nadal emigrować do Wielkiej Brytanii, http://londynek.net/wiadomosci/article?jd news_id=25782, (dostęp: 19.12.2019).

Zwoliński Ł, Mobilność przestrzenna i społeczno-zawodowa ludności wiejskiej w latach 2000 2005, nr 29, Instytut Ekonomiki Rolnictwa i Gospodarki Żywnościowej Państwowy Instytut Badawczy, Warszawa 2006, pdf na: https://www.ierigz.waw.pl/publikacje/raportyprogramu-wieloletniego-2005-2009/1314190569, (dostęp: 31.12.2019). 